\title{
Comparison of the antimicrobial activity of honey produced by Tetragonisca angustula (Meliponinae) and Apis mellifera from different phytogeographic regions of Costa Rica
}

\author{
Jason H. DEMERA*, Esther R. ANGERT \\ Departments of Entomology and Microbiology, Cornell University, Ithaca, NY 14853, USA
}

(Received 3 April 2003; revised 15 September 2003; accepted 8 December 2003)

\begin{abstract}
The purpose of the present study was to investigate and compare the demonstrated variation in antimicrobial activity of honey produced by introduced A. mellifera and the stingless bee, Tetragonisca angustula, commonly kept in hives in Costa Rica. There was no difference in activity of honey produced by Apis mellifera and T. angustula against the 5 microbes tested. Honey from different phytogeographic regions exhibited differential antimicrobial activity and susceptibility of yeasts to honey of either species was greater than that of bacteria.
\end{abstract}

Tetragonisca / Apis / antimicrobial activity / phytogeographic / Costa Rica

\section{INTRODUCTION}

The keeping of bees by different cultures for purposes of harvesting honey and wax has a long-standing tradition and history. Beekeepers and honey enthusiasts alike have long reported the medicinal qualities of honey (Ransome, 1986; Rudnay, 1987; Crane 1990; Molan, 1997). Before the introduction of Old World species such as sugarcane and Apis mellifera $\mathrm{L}$. to the New World, the only concentrated source of sweetener was "honey" 1 produced by stingless bees (Hymenoptera: Apidae: Meliponinae) and a few species of honey-making wasps (Hymenoptera: Vespidae). In Central and South America, indigenous peoples harvest honey and other hive products from native Hymenoptera through the practice of honey-hunting (Posey, 1983; Kent, 1984) and, in some locations such as the Yucatan Peninsula of Mexico (Kent, 1984; de Jong, 1999), are able to keep stingless bees (Melipona beecheii) in natural $\log$ hives akin to modern forms of apiculture.
Much "folklore" has been attached to the putative medicinal effects of honey (Ransome, 1986; Crane, 1990) and studies have been conducted to confirm these effects for honey produced by A. mellifera (Molan, 1997; Bogdanov, 1997). However, few researchers have investigated the same for stingless bee honey (Vit et al., 1994, 1998a; de Bruijn and Sommeijer, 1995; Sommeijer et al., 1995). The purpose of this study was to investigate and compare variation in antimicrobial activity of honey produced by introduced $A$. mellifera and a species of stingless bee, Tetragonisca angustula Illiger, commonly kept in hives in Costa Rica.

\section{MATERIALS AND METHODS}

\subsection{Origins of honey}

Honey samples were collected between June 16 and July 3, 2000 from six distinct phytogeographic regions of Costa Rica (Fig. 1) for use in two separate

\footnotetext{
* Corresponding author: jhd4@ cornell.edu

${ }^{1}$ According to the Codex Alimentarius honey can be only used for the "sweet substance produced by honey bees".
} 


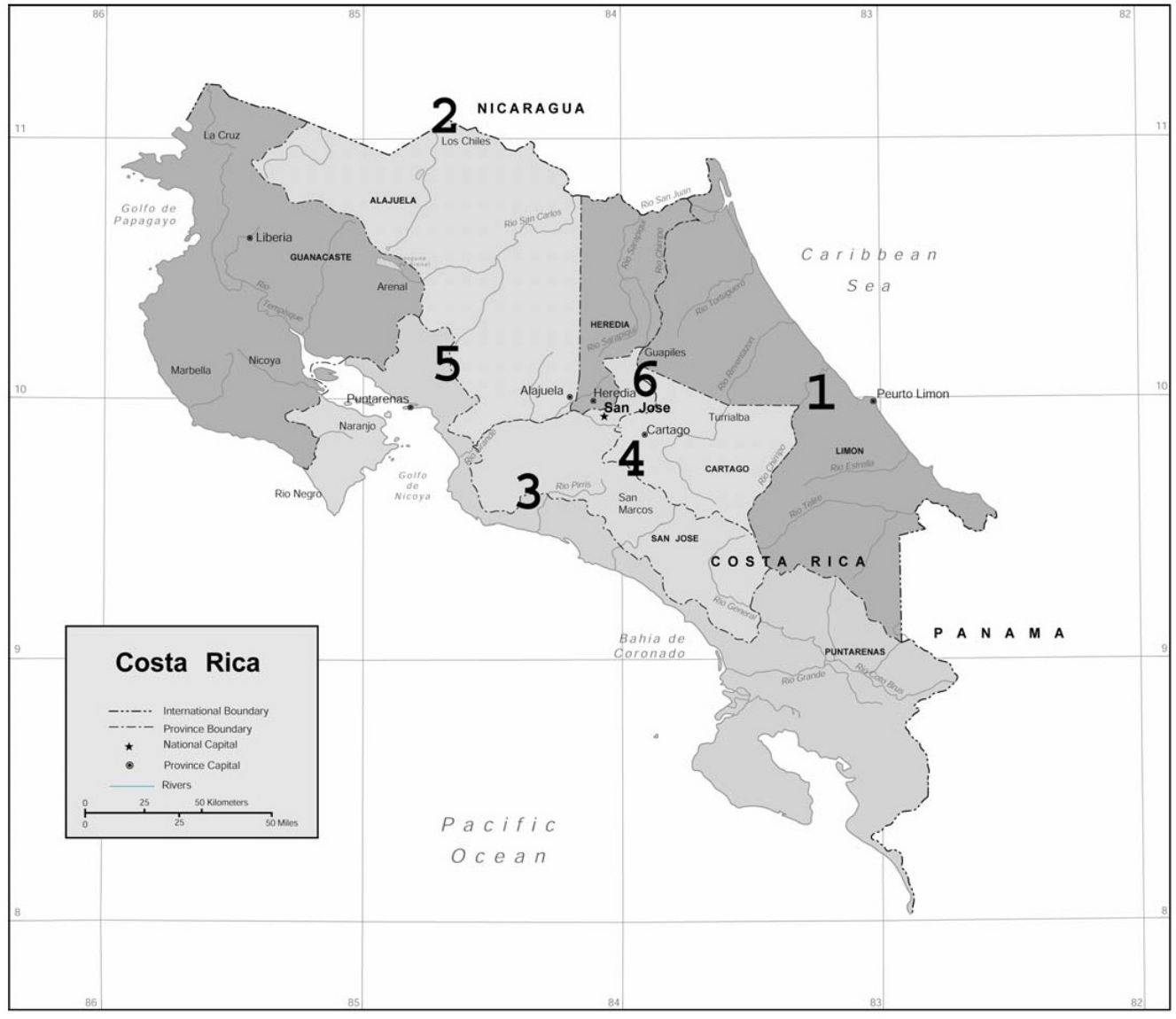

Figure 1. Political map of Costa Rica showing location of the six different phytogeographic regions from which honey samples were taken.

experiments. Honey produced by Apis mellifera was either bought directly from beekeepers (Sites 2-4) or harvested directly from the hive (Site 1). Due to seasonal production constraints, the sample size of the honeys from A. mellifera was small $(\mathrm{n}=4 ; 1$ hive each from Sites 1-4). Honey of stingless bees commonly kept in hives, Tetragonisca angustula, a honey of which is used in various local medicinal applications, was collected directly from pots within nests using sterile syringes $(n=14 ; 3$ hives each from Sites 1, 2, and 4; 2 hives each from Sites 5 and 6; 1 hive from Site 3). The six regions (Fig. 1) are characterized as follows:

1. Horquetas - Caribbean lowland forest

2. Los Chiles - Northern lowland wet forest

3. Puriscal-300-400 m above sea level, no forest, farmland
4. San Marcos de Tarrazu - 1500-2000 m, central highlands

5. El Sur de Turrubares - Pacific lowland rainforest

6. Heredia - 1100-1300 m, Central Valley

All honey samples were transferred onsite to $40 \mathrm{ml}$ amber glass vials fitted with rubber/teflon septa to protect and conserve any light sensitive compounds. Within 12 hours of collection, all honey samples were stored at 0 to $-20{ }^{\circ} \mathrm{C}$.

\subsection{Assay for inhibition of microbial growth}

Two separate experiments were performed. The first experiment compared honey from Sites 1-4 of one hive each of Apis mellifera and Tetragonisca angustula. The second experiment compared honey 
of two hives of Tetragonisca angustula only from each of Sites 1, 2, 4, 5 and 6.

Three bacteria [Bacillus cereus (G+, ATCC 31430), Pseudomonas aeruginosa (G-, ATCC 27858), Staphylococcus aureus $(\mathrm{G}+$, ATCC $6538 \mathrm{P})]$ and two yeasts [Saccharomyces cerevisiae (ATCC 287), Candida albicans (ATCC 90028)] were utilized to assay antimicrobial activity of the honeys collected. B. cereus and $P$. aeruginosa were cultured on nutrient agar (Difco 0001), S. aureus was cultured on Trypticase Soy Agar (BBL 11043), and the two yeasts S. cerevisiae and C. albicans were cultured on Sabouraud Dextrose Agar (Difco 0109) and YM Agar (Difco 0712), respectively. Media used in these studies were chosen to provide optimal growth conditions for each of the microorganisms.

The agar well diffusion method (Sommeijer et al., 1995) was employed to test the antimicrobial activity of honey of different species collected from the different regions. The larger end of a cooled, flamed Pasteur pipette was used to make four wells $(4 \mathrm{~mm}$ diameter) in microbe-specific agar media plates onto which $10 \mu \mathrm{L}$ of a suspension of a 16 hour culture of either one of three bacteria or one of two yeasts had been spread. One aliquot $(0.6 \mathrm{~mL}$ each) of A. mellifera or T. angustula honey (undiluted) from the same region was deposited into each of two of the four wells on the same Petri dish. Two replicates of each plate were made for a total of four replicate tests per honey with each of the five microbes. The plates were incubated aerobically at $37^{\circ} \mathrm{C}$ for 48 hours.

\subsection{Quantification of microbial growth inhibition}

Quantification of microbial growth inhibition was determined by measuring the diameter of zones clear of microbial growth around the wells in the agar (including the well). Four measurements per well were made at 4 different directions $\left(0^{\circ}, 45^{\circ}, 90^{\circ}\right.$, and $\left.135^{\circ}\right)$ at three time intervals $(17,24$ and 48 hours). During the first experiment, $C$. albicans cultures required 24 hours for sufficient growth and measurement. For each experiment, the data from each plate for a given honey were averaged and they were analyzed by 2-way ANOVA with the diameters of zones of inhibition as the dependent variable. Honey type and phytogeographic zone were main effects for Experiment 1 and microbe species and phytogeographic zone were main effects for Experiment 2.

\subsection{Moisture content}

Moisture content of all honey samples was taken directly in the field and again immediately before testing using a handheld Atago refractometer (Tab. I; Cox and Huser, 1996).
Table I. Average moisture content of A. mellifera and $T$. angustula used in this study (mean \pm s.d.; range; $\mathrm{n}$ ).

\begin{tabular}{lc}
\hline BEE & MOISTURE $(\%)$ \\
\hline A. mellifera & $20.30 \pm 1.73 ; 18.6-22.4 ; 4$ \\
T. angustula & $24.93 \pm 2.32 ; 22.1-28.9 ; 14$ \\
\hline
\end{tabular}

\section{RESULTS}

\subsection{Bee type and microbe type effects}

There was no significant difference in the antimicrobial activity of the two honey types over the three incubation intervals for all phytogeographic regions $\left(17 \mathrm{~h} F_{1,20}=2.15,24 \mathrm{~h}\right.$ $F_{1,24}=2.12$, 48 h $F_{1,24}=0.07 ; P=0.1585$, $0.1583,0.8005$, respectively). Interactions between honey and microbe types (data for $S$. aureus not included in this analysis as there was zero inhibition of growth) were not significant for all incubation intervals $\left(17 \mathrm{~h} F_{3,20}=0.06\right.$, $24 \mathrm{~h} F_{3,20}=0.24,48 \mathrm{~h} F_{3,24}=0.86 ; P=0.9797$, $0.8655,0.4777$, respectively; Fig. 2).

\subsection{Site and microbe type effects}

Differences in the average diameters of zones of inhibition produced by $T$. angustula honey among the 4 microbe types tested were found at all 3 incubation intervals $\left(17 \mathrm{~h} F_{2,15}=\right.$ $10.21 ; 24$ h $F_{3,20}=29.45 ; 48$ h $F_{3,20}=23.06$; $P=0.0016,<0.0001,<0.0001$, respectively; Fig. 3).

Significant differences in the antimicrobial activity of $T$. angustula honey from different phytogeographic regions were found during the last two incubation intervals $\left(24 \mathrm{~h} F_{4,20}=\right.$ $3.48 ; 48 \mathrm{~h} F_{4,20}=3.34 ; P=0.0259$ and 0.0299 , respectively). Mean separation tests (Tukey) revealed significant differences between Site 2 and 4 (Fig. 4).

Interactions between honey and microbe types were insignificant for all incubation intervals $\left(17 \mathrm{~h} F_{8,15}=0.18 ; 24 \mathrm{~h} F_{12,20}=0.50 ; 48 \mathrm{~h}\right.$ $F_{12,20}=0.56 ; P=0.9900,0.8914,0.8478$, respectively).

\subsection{Site effects and microbe group comparisons}

Measurements for the antimicrobial activity of $T$. angustula honey were grouped by microbe 


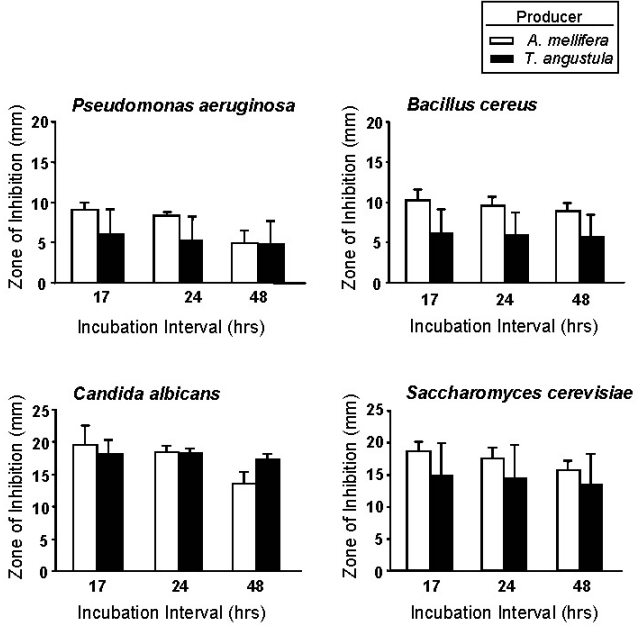

Figure 2. Average diameter of zone of inhibition (mean $\pm \mathrm{SE}$ ) for four of five microbes tested (growth of Staphylococcus aureus was not inhibited by either honey) against honey produced by A. mellifera and $T$. angustula from Sites 1-4 (all $P>0.05$ ).

(bacteria and yeast). Separate analyses were performed for each incubation interval. Phytogeographic region influenced the antimicrobial activity of $T$. angustula honey against bacteria and yeasts at 24 and 48 hours $\left(24 \mathrm{~h} F_{4,30}=3.38\right.$; 48 h $F_{4,30}=2.99 ; P=0.0215,0.0343$, respectively).

To discern differences in the susceptibility of groups of microbes to A. mellifera and $T$. angustula honey, the data were subjected to 2-way ANOVA (SAS V8, 2000) and followed up with contrast analysis. There were no differences in susceptibility between pairs of bacteria and pairs of yeasts. However, yeasts as a group had a greater susceptibility to both A. mellifera (data not shown) and T. angustula (Fig. 5) honey than bacteria as a group did at all 3 incubation intervals $\left(17 \mathrm{~h} F_{1,20}=26.01\right.$; $24 \mathrm{~h} F_{1,30}=77.92 ; 48$ h $F_{1,30}=52.77$; all $P<$ 0.0001) (Fig. 4).

\section{DISCUSSION}

There exists a belief among Latin American honey users that honey produced by native stingless bee species is more 'powerful' medicinally than that produced by the introduced A. mellifera (DeMera, unpublished data; Weaver
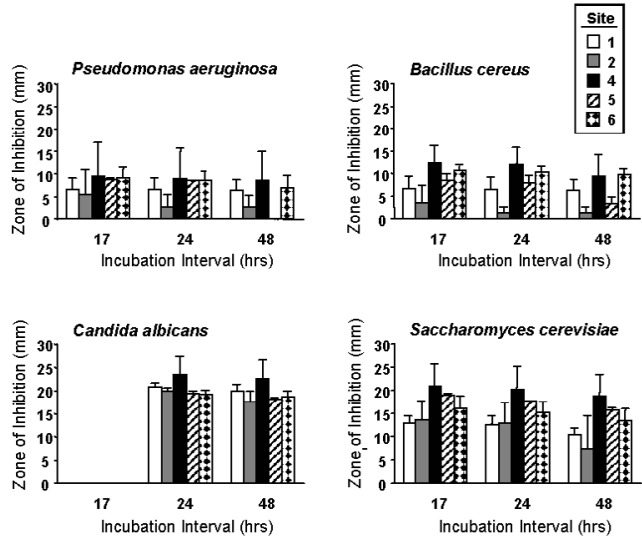

Figure 3. Diameter of zone of inhibition (mean \pm $\mathrm{SE}$ ) for four of five microbes tested against honey produced by $T$. angustula from 5 sites at 3 different incubation intervals. Individual analyses were carried out for each incubation interval.

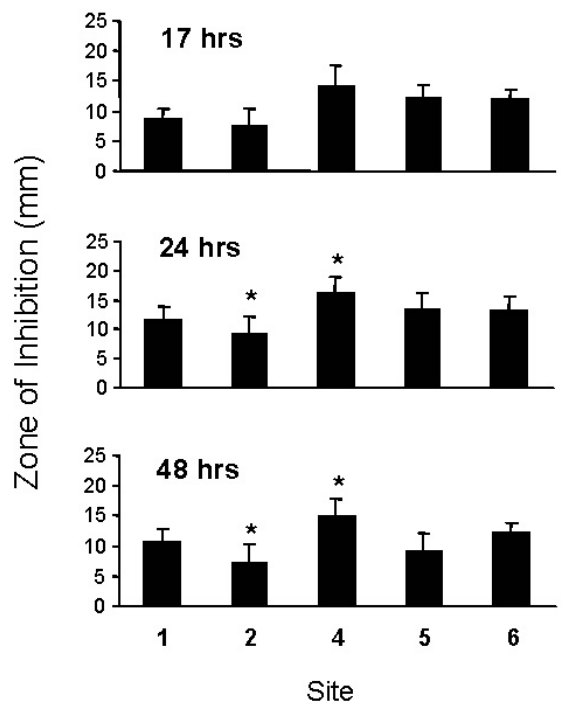

Figure 4. Diameter of zone of inhibition (mean \pm $\mathrm{SE}$ ) produced by $T$. angustula honey from 5 sites at 3 different incubation intervals averaged for all microbes. Individual analyses were carried out for each incubation interval. (*) indicates significant differences.

and Weaver, 1981; Sommeijer et al., 1995). Several factors may influence the antimicrobial activity of honey. They include, but are not limited to, its physicochemical properties, botanical origin, entomological origin, and symbioses with beneficial bacteria. Here, in part, 

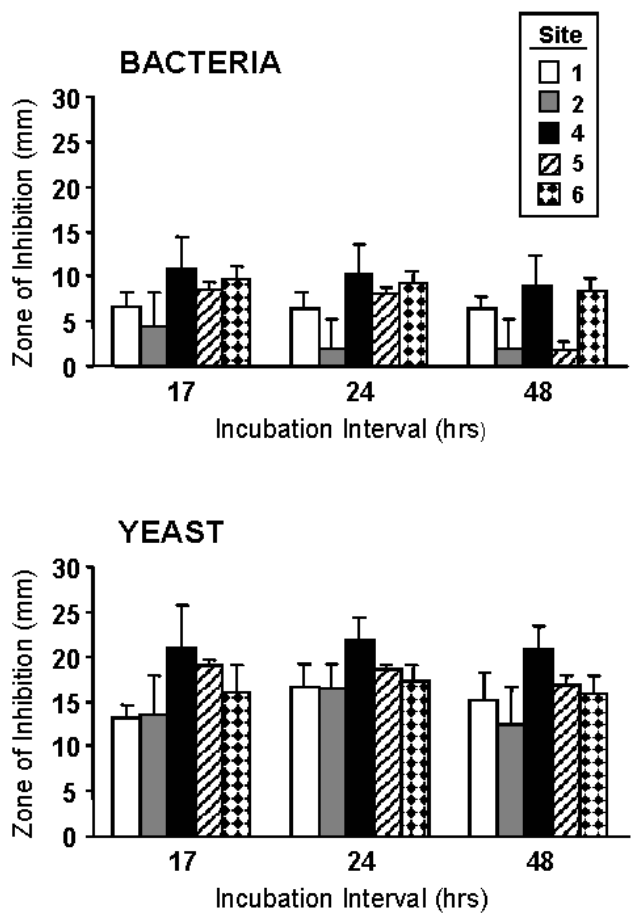

Figure 5. Diameter of zone of inhibition (mean \pm SE) against groups of microbes by honey produced by $T$. angustula from 5 sites at 3 different incubation intervals. Individual analyses were carried out for each incubation interval.

the relative contributions of the honey's botanical and entomological origins have been investigated.

We found that the claim that stingless bee honey is more active medicinally than honey bee honey cannot be substantiated. Honey of different entomological origin from the same phytogeographic region did not differ statistically from one another in their abilities to inhibit the growth of bacteria and yeasts. While no influence of entomological origin on antimicrobial activity was found in this study, its importance should not be overlooked. Honey from different phytogeographic regions varied in its ability to inhibit the growth of bacteria and yeasts suggesting that botanical origin plays an important role in influencing a honey's antimicrobial activity.

Early studies comparing the antimicrobial properties of honey from A. mellifera with honey from stingless bees of the genus Melipona demonstrated that stingless bee honeys exhibited a stronger antimicrobial effect (Sommeijer et al., 1995; Vit et al., 1994). However, these studies did not provide detailed information concerning the phytogeographical origins of the samples. Therefore the relative contributions of entomological and botanical effects cannot be assessed. However, subsequent studies provide evidence that phenolic compounds, particularly flavonoids, are responsible for antimicrobial properties of honeys (Bogdanov, 1997; Vit et al., 1998a, 1998b). Flavonoid profiles were found to vary with phytogeographical origin and not entomological origin. Our results demonstrating strong phytogeographical differences in antimicrobial activity are consistent with these observations.

There exists a higher risk of fermentation in honey with higher water content, such as stingless bee honey. Results for water content are consistent with Sommeijer et al. (1995) for honey of stingless bees and honey bees (Tab. I). It is interesting to note that $T$. angustula honey had higher average water content than $A$. mellifera honey. However, the two honeys did not differ in their antimicrobial activity against the microbes tested (Fig. 2) and therefore the observed results cannot be attributed to an osmotic effect.

More studies are needed to fully assess the contribution of entomological origin, flora and flowering phenologies to the antimicrobial activity of stingless bee honeys. Future investigations should include comparisons of hive products from as many meliponine species, phytogeographic regions, and flowering seasons as possible to identify particular factors which dictate the antimicrobial activity of honeys.

Differences in microbial susceptibility also warrant further investigation. Staphylococcus aureus, a Gram Positive bacterium, was not susceptible to any of the treatments in this study, while $B$. cereus (also a Gram Positive bacterium) was susceptible. It would be interesting to investigate variation in protective mechanisms of strains of $S$. aureus, especially in light of its emergence as a multiple antibiotic resistant wound infecting bacterium (Gulati et al., 1996; Anand and Shanmugan, 1998; Cooper et al., 1999). 
The insect world is a relatively untapped resource in the search for efficacious natural products. Due to its biochemical diversity the microbial world has the potential to be an even greater resource for bioactive natural products. For this reason, efforts are needed to further characterize the mechanisms of the beneficial microbial symbioses of bees. These should include a comparative survey of the gut flora of the Apidae and the identification and isolation of any antimicrobial compounds produced.

\section{ACKNOWLEDGEMENTS}

Many thanks go to Dr. Darryl Scott Vargas (MAC), Dr. J.C. Biesmeijer, everyone at CINAT, Dr. Thomas D. Seeley, Dr. Nicholas W. Calderone, Dr. Françoise Vermeylen, and, of course, to all the beekeepers who provided honey samples. Partial funding was obtained through SUNY Minority Graduate Fellowships and the National Science Foundation.

Résumé - Étude comparée de l'activité antimicrobienne du miel de Tetragonisca angustula (Meliponinae) et d'Apis mellifera provenant de diverses régions phytogéographiques du CostaRica. L'activité antimicrobienne du miel d'Apis mellifera $\mathrm{L}$. a fait l'objet de nombreuses recherches mais la même attention n'a pas été portée à celui produit par les abeilles sans aiguillon (Meliponinae). Outre sa valeur en tant que source de sucre concentrée, le miel est souvent utilisé comme remède. Les consommateurs de miel du monde entier présentent des différences dans le comportement d'achat basées sur l'action médicinale supposée de certains miels. En Amérique latine de nombreux consommateurs croient que le «miel» produit par les espèces d'abeilles indigènes est plus actif du point de vue médicinal que le miel produit par l'Abeille domestique introduite. Le but de cette étude était d'étudier et de comparer l'activité antibactérienne du miel d'Apis mellifera et de celui de Tetragonisca angustula Illiger, abeille sans aiguillon couramment élevée en rucher au Costa-Rica. La méthode de diffusion sur gélose a été utilisée pour quantifier les différences dans l'activité antimicrobienne globale de ces miels provenant de diverses régions phytogéographiques. Aucune différence n'a été enregistrée entre les miels des deux espèces d'insectes, bien que le «miel» de T. angustula ait en moyenne une teneur en eau plus élevée (Tab. I). Néanmoins la capacité globale du miel de chaque espèce à inhiber la croissance bactérienne a varié d'une région phytogéographique à l'autre (Fig. 3). En outre on a trouvé que les levures testées étaient plus susceptibles que les bactéries à l'activité antimicrobienne
(Fig. 4). De nombreuses causes possibles de variation de l'activité antimicrobienne doivent encore être étudiées. Nous recommandons qu'outre les études de l'efficacité inhibitrice des différents miels vis-à-vis des microbes et des maladies qui leur sont liées, les futures études incluent la comparaison des produits de la ruche d'un nombre aussi grand que possible d'espèces de Meliponinae, de régions phytogéographiques et de périodes de floraison, afin de déterminer la contribution relative de ces divers facteurs à l'activité antimicrobienne. En particulier, les constituants chimiques des miels des sites présentant la plus forte activité pourraient être analysés et comparés.

Tetragonisca angustula / Apis mellifera / activité antimicrobienne / miel / région phytogéographique / Costa-Rica

Zusammenfassung - Vergleich antimikrobieller Aktivität im Honig von Tetragonisca angustula (Meliponinae) und von Apis mellifera aus unterschiedlichen pflanzengeographischen Regionen in Costa Rica. Es gibt viele Untersuchungen über die antibakterielle Aktivität von A. mellifera L. Honig, während dem Honig der Stachellosen Bienen (Meliponinae) bisher nur wenig Beachtung geschenkt wurde. Außer seinem Wert als konzentrierte Zuckerquelle wird Honig häufig auch als Heilmittel angewendet. Auf Grund der mutmaßlichen medizinischen Wirkung von bestimmten Honigen gibt es grundlegende Unterschiede im Kaufverhalten der Honigkunden in der ganzen Welt. Viele lateinamerikanische Honigkunden glauben, dass der Honig von einheimischen Bienenarten medizinisch aktiver ist als der der eingeführten Honigbiene A. mellifera. Ziel unserer Untersuchung war eine weitergehende Erfassung und ein Vergleich der antimikrobiellen Aktivität des Honigs von A. mellifera und einer Art der Stachellosen Bienen, Tetragonisca angustula Illiger, die häufig in Beuten in Costa Rica gehalten wird. Für die Qantifizierung der allgemeinen antimikrobiellen Aktivität von Honigen aus verschiedenen pflanzengeographischen Regionen wurde eine Agar-Diffusionsmethode benutzt. Es ergab sich kein Unterschied in der Aktivität des Honigs zwischen den beiden Arten (Abb. 2), obwohl der Honig von T. angustula einen höheren durchschnittlichen Wassergehalt aufwies als der von A. mellifera (Tab. I). Dagegen unterschied sich die allgemeine Fähigkeit der Honige das Mikrobenwachstum zu verhindern in Abhängigkeit von der pflanzengeographischen Herkunft (Abb. 3). Zusätzlich zeigte sich, dass die getesteten Hefestämme empfindlicher auf die antimikrobielle Aktivität des Honigs reagierten als Bakterien (Abb. 4). Die vielen möglichen Ursachen für die Unterschiede in der antimikrobiellen Aktivität der verschiedenen Honige bedarf weiterer Untersuchungen. Neben den Studien über eine wirksame Verminderung von spezifischen Mikroben und den damit verbundenen Krankheiten, sollten unserer 
Meinung nach zukünftige Untersuchungen den Vergleich von Bienenprodukten möglichst vieler Arten der Meliponinen, sowie verschiedener pflanzengeographischer Regionen und Blühphasen einschließen. Damit könnte der relative Beitrag unterschiedlicher Faktoren zur antimikrobiellen Aktivität bestimmt werden. Im besonderen könnten dann die chemischen Bestandteile der Honige aus den Regionen mit der höchsten Wirksamkeit analysiert und verglichen werden.

\section{Tetragonisca / Apis / antimikrobielle Aktivität / Pflanzengeographie / Costa Rica}

\section{REFERENCES}

Anand S., Shanmugam J. (1998) Anti-staphylococcal properties of natural Honey, Biomedicine 18, 1518.

Arce-Arce H.G., van Veen J.W., Sommeijer M.J. (1994) Beekeeping with stingless bees (Hymenoptera: Apidae, Meliponinae) in Costa Rica, Proc. Vth Int. Conf. on apiculture in tropical climates IBRA, pp. 209-213.

Bogdanov S. (1997) Nature and origin of the antibacterial substances in Honey, Lebensm. -Wiss. Technol. 30, 748-753.

Cooper R.A., Molan P.C., Harding K.G. (1999) Antibacterial activity of honey against strains of Staphylococcus aureus from infected wounds, J. R. Soc. Med. 92, 283-285.

Cox B., Huser B. (1996) Moisture level and color of honey, Am. Bee J. 136, 253-257.

Crane E. (1990) Bees and beekeeping: science, practice and world resources, Heinemann Newnes, Oxford, $614 \mathrm{p}$.

de Bruijn L.L.M., Sommeijer M.J. (1995) The composition and properties of honeys of stingless bees (Melipona), in: Perspectives for Honey Production in the Tropics Proc. Vth Int. Conf. on apiculture in tropical climates IBRA, pp. 149-168.

de Jong H.J. (1999) The Land of Corn and Honey: The keeping of stingless bees (meliponiculture) in the ethno-ecological environment of Yucatan
(Mexico) and El Salvador, Utrecht University Press, Netherlands, $423 \mathrm{p}$.

Gulati R., Gulati B.R., Sihag R.C. (1996) Antibacterial activity of propolis and honey against Staphylococcocus aureus and Escherichia coli, Indian Bee J. 58, 128-130.

Kent R.B. (1984) Mesoamerican stingless beekeeping, J. Cult. Geogr. 4, 14-18.

Molan P.C. (1997a) The antibacterial activity of honey. 1 . The nature of the antibacterial activity, Bee World 73, 5-28.

Molan P.C. (1997b) The antibacterial activity of honey. 2. Variation in the potency of the antibacterial activity, Bee World 73, 59-76.

Posey D.A. (1983) Folk apiculture of the Kayapo Indians of Brazil, Biotropica 15, 154-158.

Ransome H.M. (1986) The sacred bee in ancient times and folklore, Burrowbridge Somerset, England, $308 \mathrm{p}$.

Rudnay J. (1987) A book of Honey: It's history and use, Budapest, Corvina, 114 p.

Sommeijer M.J., Beetsma J., Boot W.J., Roberts E.J., de Vries R. (1995) Perspectives for Honey Production in the Tropics, Proc. Symp. organized by the Netherlands Expertise Centre for Tropical Apicultural Research (NECTAR), Utrecht, Netherlands, Dec. 18.

Vit Olivier P., Rios de Selgrad A.M., Novoa M.L., Reinosa Fuller J., Camargo J. (1994) Antibacterial activity and mineral content of Venezuelan stingless bee honeys, Proc. Vth Int. Conf. on apiculture in tropical climates IBRA, pp. 254-258.

Vit P., Tomás-Barberán F.A. (1998a) Flavonoids in Meliponinae honeys from Venezuela related to their botanical, geographical, and entomological origin to assess their putative anticataract activity, Z. Lebensm.-Unters.-Forsch. 206, 288-293.

Vit P., Oddo L.P., Marano M.L., de Mejias E.S (1998b) Venezuelan stingless bee honeys characterized by multivariate analysis of physicochemical properties, Apidologie 29, 377-389.

Weaver N., Weaver E.C. (1981) Beekeeping with stingless bees Melipona beecheii, by the Yucatecan Maya, Bee World 62, 7-19. 